平成 3 年レーザー学会学術講演会第11回年次大会

$31 \mathrm{p} \mathrm{V} 1$

(招待講演)

高性能エキシマレーザーの開発

通库省大型プロジエクトによる—

「超先端加エシ久广厶技術研究組合」技術委員長

株式会社東芝北村守

1.はじめに

エネルギー、精密機械、エレクトロニ クス、航空・宇宙などの先端技術産業は、 将来わが国の産業を支える柱として重視 されている。そこでは、原子・分子レべ ルの制御が可能な超精密 - 超微細加工、 超高品位表層改質加工など、従来には無 い新技術の開発が不可欠となる。

これらの実現に向けて、通産省工業技 術院は、大型プロジェクト制度に基づき 「超先端加エシステムの研究開発」を、 昭和 61 年度より 8 年間、総額約 150 億円の予算で実施することとした。この 大要は、大出力エキシマレーザー、高密
度イオンビーム、超精密機械加工装置と、 これらを使つた超先端加工処理技術およ びその計測評価をする支援技術を開発し、 総合実証としてトータルシステムの構築 をするための概念設計を行う、というも のである。

現在、これには各産業分野から18 社 ・ 3 団体が参加して、多岐にわたる高度 な研究項目の開発を組織的かつ効来的に 進めている。ここでは、本プロジェクト におけるエキシマレーザ一の開発内容と、 中間成果について報告する。

なお、「3. 要素技術の開発状況」の 主要部は文献1）～6）の抄録である。

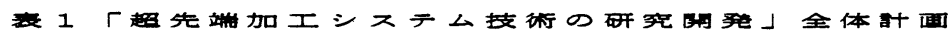

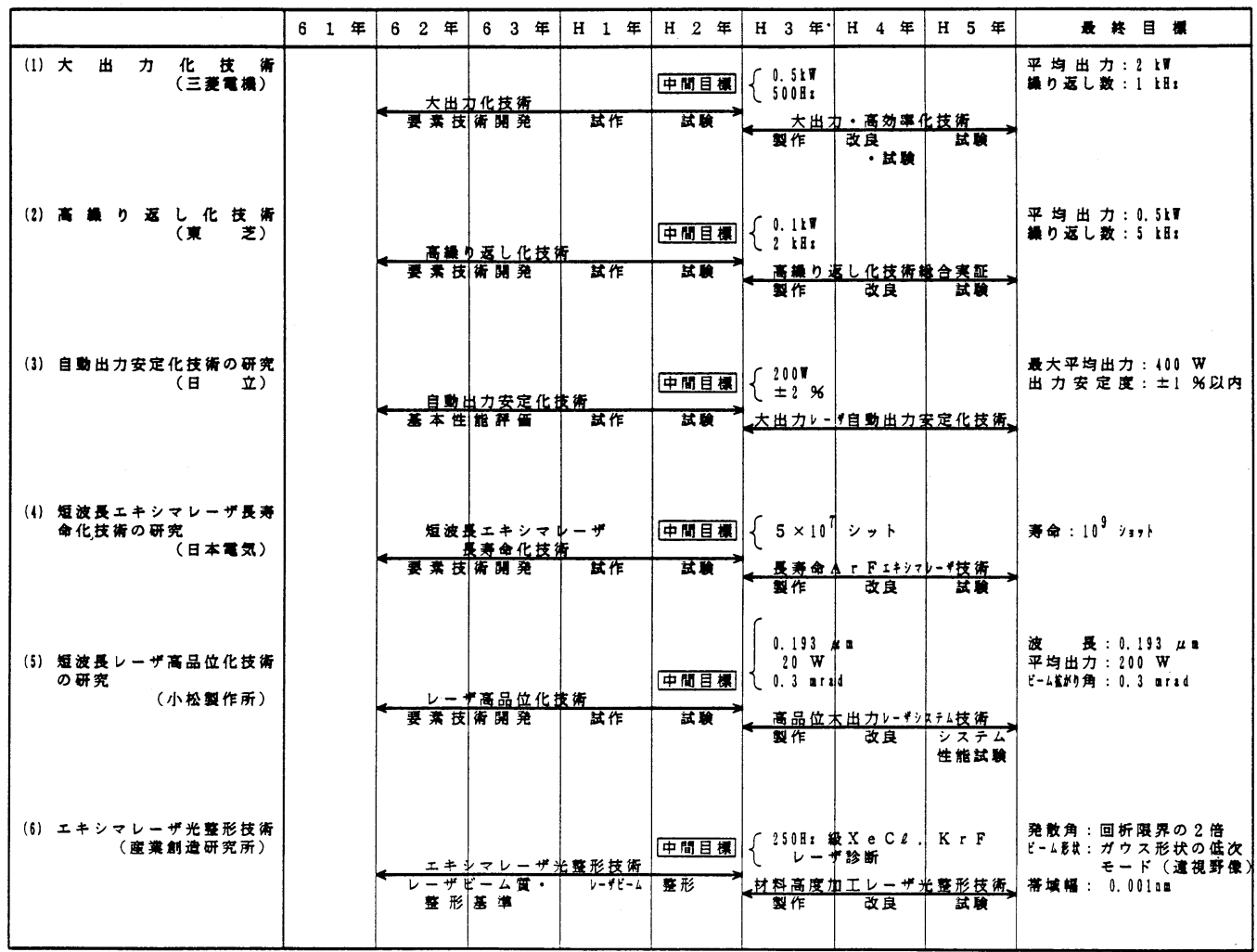


2. 研究開発計画の概要

言うまでもなく、エキシマレーザーは、 光子エネルギーの高い紫外域において、 大出力・高効事パルス発振が得られるの で、従来の熱作用に対し、光化学作用を 使う新しい加工処理に有力であり、実用 化への期待はきわめて大きい。

そこで、超先端加工処理技術の確立を 目指す本プロジェクトでは、大出力化、

高安定化、高品位化などにより、総合的 に高性能エキシマレーザーの実用化を図 ることが、最重点開発項目になっている。 表 1 は、これらの開発項目とスケジュ一 ル、および中間 · 最終目標值をまとめた ものである。

\section{3. 要素技術の開発状況}

(1) 大出力化 (担当: 三菱電機) 1) 新しいコンセプトの放電励起方式によ り、約 $1 \mathrm{~J}$ の単パルス出力を実現すると 共に、繰返し発振に不可欠な同軸コンデ ンサ型 P F N 回路素子やレーストラック 型磁気飽和素子を開発した。図1に2つ

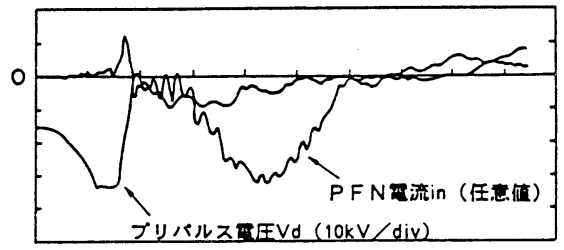

同方向酯圧モード

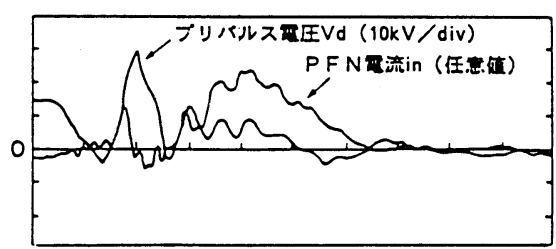

時間 $\mathrm{t}(100 \mathrm{~ns} / \mathrm{div})$

反転政压モート

図1プリパルス $\mathrm{P} F \mathrm{~N}$ 回路の 電圧電流波形
の電圧モードにおける、電流、電圧波形 およびレーザー出力波形を示す。

加えて、低電力ガス循環技術や固体ス イッチング素子と磁気パルス圧縮回路を 組み合わせたスイッチ技術などの要素技 術開発を進め、放電励起技術と一体化す ることにより繰返し実験装置として具現 化した。

同装置で取得した放電特性、レーザー 発振特性をべースに改良を加え、500 $\mathrm{W}$ 達成に向けて研究開発を推進中である。

（2）高繰返し化（東芝） 2 )

当年度は、中間評価に向けて、第 1 次 モデル装置の設計・試作を主体に進めた。

基礎実験装置にて、国内外を通しての 記録值、パルス繰返し数 $2.5 \mathrm{kH} \mathrm{Z}$ 、平 均出力 $87 \mathrm{~W}$ のレーザ一発振動作を確認 し(図2）、中間目標達成見通しを得た。

さらに、高速ターンオン半導体スイッ チング素子についても、電流立ち上がり 率 $40 \mathrm{kA} /\left(\mu \mathrm{s} \cdot \mathrm{c} \mathrm{m}{ }^{2}\right)$ というサイ ラトロンの性能を越える高速性が基本特

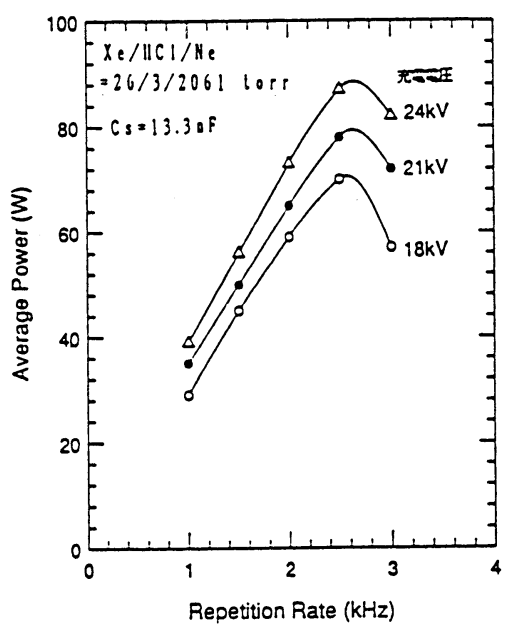

図 $2 \mathrm{~N}$ e 希积における繰返し数 対レーザー出力特性 
性として確認できた。

しかしながら、この要素実験において、 $3 \mathrm{kH} \mathrm{z}$ 以上の高絽返し領域では、ガス 下流アーク放電とは別の原因と推察され るレーザー出力の飽和や不安定現象がみ られており、下流アーク放電の原因究明 も合わせて今後の重要課題として残され ている。

\section{（3）出力安定化（日立） ${ }^{3}$ )}

$20 \mathrm{O}$ X e C 1 エキシマレーザーを 用いて 63 年度までに得られた、ガス系 制御主体の出力安定化技術を基礎に、平 成元年度はH C 1 の消耗、予備電離放電 の出力低下への影響、不純物の分析等の 故電に伴うガス劣化要因について検討し、 より大出力時の出力安定化に不可欠な基 本特性を得た。さらに、より高精度の安 定化のための制御アルゴリスムを作成し、 これを $20 \mathrm{~W}$ 装置に適用し、出力 $20 \mathrm{~W}$ 、 安定度 $\pm 2 \%$ を 8 時間に渡つて検証した (図 3 ) 。また、平成 2 年度の中間評価 用 $200 \mathrm{~W}$ 装置のガス循環部を製作し、

所期のガス流速特性を得た。これらによ り、平成 2 年度の中間目標達成に向けて 大きな見通しを得た。

\section{（4）長寿命化（日本電気） $\left.{ }^{4}\right)$}

革新的な試みであるメ夕ル多用、セラ ミック使用の長寿命化 $\operatorname{ArF} キ$ シ マレー

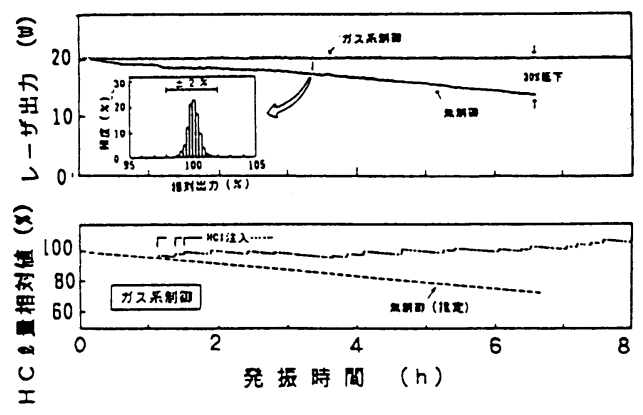

図3 出力安定化制御例 ( $20 \mathrm{~W}$ 装置)
ザーを設計し、目的通りガス劣化の主要 因と考えられる不純物 $\mathrm{CF}_{4}$ の発生が抑え られ、従来に倍する $2.1 \times 10^{6}$ ショットのガス 寿命を得た（図４）。不純物ガス CF 4 の 除去方法の確立などを行い、ガス再生装 置を上記長寿命化 ArFエキシマレーザ一 に取り付けた寿命試験にて、3×106ショット までの予備的試験ではあるが、レーザー 出力を一定に維持できた。しかし、ガス 再生装置の動作直後に、レーザー出力が 急激に減少し、 $\mathrm{CF}_{4}$ 以外の不純物ガスの発 生が予想された。

励起回路としてスパ仂ーサステイナを採り上げ 高効率発振化のための知見を得た。さら に、X線予備電離の開発では、長寿命に 重要な陰極温度の低温化などを実現した。

（5）高品位化（小松製作所）５）

エ夕ロン用コート膜の損傷しきい值を、 A r F レーザー発振光を用いた散乱光計 測により、高精度に、再現性良く定量化 する方法を確立した。この結果、コート 膜の耐光強度はメ一力によりかなり大き な差があることが判明した。

波長モニタ一系の波長標準としては、

$\mathrm{H}$ g スペクトル線が最適であった。

低繰返し動作で、 $1 \mathrm{c} \mathrm{m} \mathrm{m}^{-1}$ 以下の注入 同期に成功した。增幅段のスペクトル波 形を図 5 に示す。

高繰返し対応の発振段、 $\sigma=1.3 \mathrm{n}$ $\mathrm{s}$ の低ジッタトリガ回路、おょび、 3. $5 \mathrm{k} \mathrm{W}$ と $7 \mathrm{k} \mathrm{W}$ 電源を試作した。

今後、增幅段、パルストリガ回路、波 長制御系などを試作し、性能実験を行い、

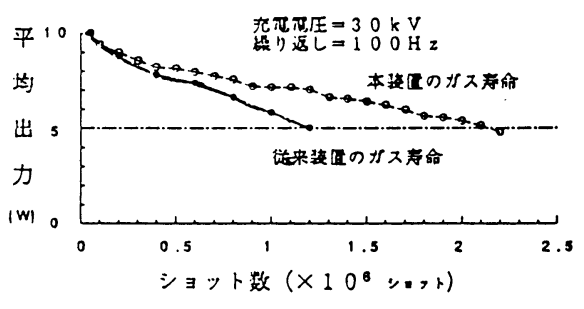

図4 ガス寿命（レーザー単体時） 
中間目標を実証するレーザーシステムを 完成させる予定である。

(6) 光整形(産業創造研究所) 61 位相共役波を発生させる媒質としては S F。ガスが良好であった。位相共役を用 いた高出力化に際しては、偏光子のダメ ージがネックとなる。誘導ラマン散乱を 用いた波長変換については、ガスフロ一 により高絽返しが可能であり、今後変換 効率の向上と変換ビームの品質を向上さ せる必要がある。ラマン変換効事の絽返 し数依存性を図6に示す。

セグメント鏡については、強度分布の 均一性が得られたので長時間使用に耐え られるよう玲却方法を考える必要がある。 ビーム結合器については波形整形のアル ゴリスムが確立され、光学パスの延長や 操作性の向上が必要である。

4. 成果と今後の課題 · 展開

上述のように、実用に耐え得るエキシ マレーザー技術の確立には、なお多くの 要素開発を必要とするが、今年度に予定 されている中間評価に対しては、いずれ の研究開発項目についても、目標達成で きる見通しが得られた。

また、いくつかの点では、すでに世界 的記録值を書き直すような成果も報告し ており、次の最終目標に向けての準備が 順調に進められている。

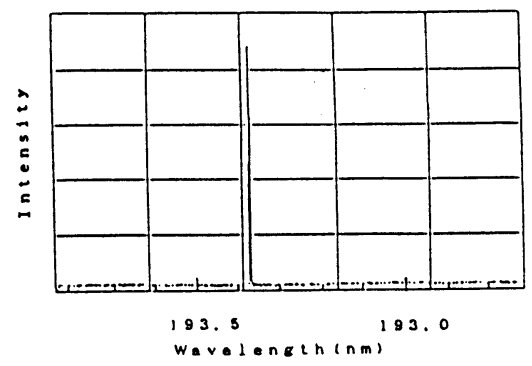

図 5 増幅段スペクトル波形
これまでの成果は、新聞・学会発表、 学術誌揭載など 143 件 ( H 2 - 8 月末 現在)があり、国内に留まらず諸外国か らも注目の的とされるまでになつた。

\section{5.おわりに}

ここでは、通産大プロ「超先端加エシ ステムの研究開発」における、高性能工 キシマレーザーの開発状況について述べ、 多くの成果から、これが本プロジェクト を支える基盤となり得ることを示した。

エキシマレーザーが、将来の実用に際 し、もっとも効果的に使われ威力を発揮 するのは、イオンビームと共にその利用 技術を基盤とした、総合的な超先端加工 技術の確立にあると言っても良いだろう。

なお、本研究は、新エネルギー・産業 技術総合開発機構の大型工業技術研究開 発「超先端加エシステムの研究開発」一 環としてなされたものである。

\section{6. 引用文献}

1 ) 春田: 第 2 回超先端加エシステム技術 シンポジウム予稿集、A-5（1990)18。

2 ) 後藤： ibid.、A-7(1990) 26 .

3) 川久保: ibid.、A-6(1990) 22 .

4) 堀田: ibid.、A-3(1990)10.

5 ）板倉：ibid.、A-4(1990) 14 .

6 )八木： ibid.、A-9(1990) 34 .

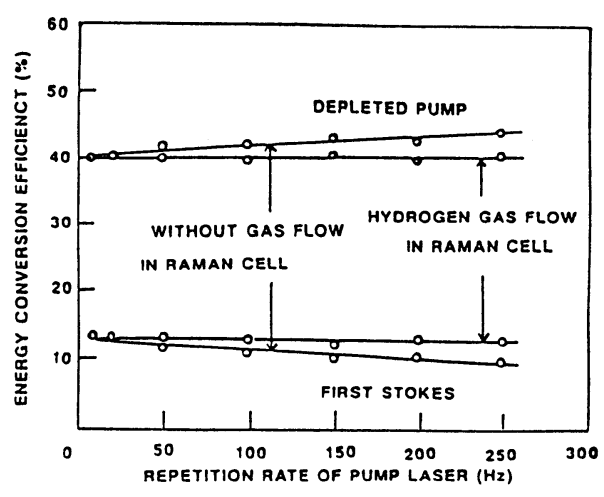

図 6 ラマ:変換効率の

繰返し数依存性 